Indian J Anim Health (2021), 60(1) : 77-89

DOI: 10.36062/ijah.60.1.2021.77-89

\title{
Lethal toxicity assessment of castor bean (Ricinus communis) seed as fish toxicant and its residual effect on water quality in aquaculture
}

\begin{abstract}
A.Mandal $^{1 *}$ and S. O. Khairnar ${ }^{1}$
${ }^{1}$ Department of Aquaculture, College of Fisheries, Guru Angad Dev Veterinary and Animal Sciences University, Ludhiana- 141 004, Punjab, India

Abstract

The present study was conducted to evaluate the minimum concentration and lethal toxicity of castor bean seed (CBS) effect on tilapia (Oreochromis mossambicus: $3.81 \pm 0.01 \mathrm{~cm}, 1.76 \pm 0.2 \mathrm{~g}$ ) for 24 hours in glass aquaria with four treatments with three doses i.e.T1 $\left(225 \mathrm{mgL}^{-1}\right), \mathrm{T} 2\left(250 \mathrm{mgL}^{-1}\right), \mathrm{T3}\left(275 \mathrm{mgL}^{-1}\right)$ followed by residual effect of CBS on Amur carp (Cyprinus carpio haematopterus: $4.32 \pm 0.03 \mathrm{~cm}, 1.82 \pm 0.4 \mathrm{~g}$ ) for 14 days in same glass aquaria with same treatments and one control (without CBS). The absolute mortality rate was recorded highest in T3 (95\%) and lowest in T1 $(60 \%)$. The $50 \%$ mortality was recorded within 3-4 hours of CBS powder application (ca.235 $\left.\mathrm{mgL}^{-1}-240 \mathrm{mgL}^{-1}\right)$ which can be considered as $\mathrm{LD}_{50}$ of $\mathrm{CBS}$ powder. The mortality rate of Amur carp decreased below $10 \%$ after the $7^{\text {th }}$ day of $\mathrm{CBS}$ application in all the treatments. Water qualities were within the optimum range except for $\mathrm{pH}$ which decreased to acidic levels $(5.7$ - 6.8) in all the treatments. Nitrogen and phosphorus ratio in water increased with the increase of CBS doses which could be due to more nitrogen input through CBS. It is concluded that CBS can be used as a potential piscicide in aquaculture with minimal residual effects with optimum doses at $225-250 \mathrm{mgL}^{-1}$ which subsequently will act as organic manure upon decomposition as culture progress.
\end{abstract}

Keywords: Amur carp, Castor bean, $\mathrm{LD}_{50}, \mathrm{~N}: \mathrm{P}$ ratio,Tilapia, Toxicity

\section{INTRODUCTION}

Aquaculture is the fastest-growing food producing sector throughout the world with an annual growth rate of 5.8\% (FAO, 2020). The aquaculture industry is facing limitations to utilize freshwater resources due to the everincreasing population, water scarcity, land acquisition cost, and indiscriminate use of drugs and chemicals. Some of the unutilized village and roadside ponds can be brought under aquaculture through cleaning of weeds and removal of unwanted fish species by application of piscicidal agents, preferably of plant origin. This can be one of the judicious approaches for the enhancement of fish production through effective utilization of available nutrients and the ecological niches in a pond. Bioaccumulation and biomagnifications of drugs and chemicals used in aquaculture have led to various health issues in fish as well as in humans. To avoid such ill effects, plant-derived toxic components had been introduced in India (Chatterjee and Ganguli, 1993; Das et al., 2017). Plants belonging to different families are also having different kinds of toxic substances like alkenyl phenols, alkaloids, saponins, tannins, di and triterpenoids, which can be used to control the unwanted organisms and predatory fish species in aquaculture (Tiwari and Singh, 2003; Katewa et al., 2005). Toxicity of such substances usually reduces within 10-15 days and the restoration of ecological status can be done upon decomposition of such substances which will enhance nitrogen and phosphorous ratio $(\mathrm{N}: \mathrm{P})$ in the pond (Mahapatra and Thosar, 1999; Das et al., 2017).

Besides the use of different plant derivatives like mohua oil cake, tea seed cake, derris root powder, tobacco waste, castor bean seed powder, etc. can be a good source of piscicide for application in aquaculture (Das et al., 2018). The extensive cultivation of castor in arid and semi-arid states leads to India as the

*Corresponding Author 
top castor producing country in the world (Anjani, 2014). Generally, castor bean contains a high amount of oil (40\%), ricin $(1 \%-5 \%)$ and ricinine $(0.3 \%-0.8 \%)$ (Johnson et al., 2005) and also contains toxic glycoproteins, ricinoleic acid (12-hydroxyoleic acid) and the alkaloid ricinin (EFSA, 2008). Total four types of toxic ricins $(\mathrm{A}, \mathrm{B}, \mathrm{C}$, and D) appear in small and large grains of castor bean plant (Lin and Li, 1980; Woo et al., 1998). Ricin acts as a cytotoxic protein which usually inhibits the protein system that causes cell death (Audi et al., 2005). Therefore, powder of castor bean seed can be used as a potent piscicidal agent in aquaculture (Mandal and Das, 2019).

The improvement and regeneration of the productive status of the pond system are usually dependent on the available nutrient status of the system. The increase in N:P ratio and acceleration of primary productivity; both depend on the availability of carbon, nitrogen and phosphorus level. The application of organic manure or inorganic fertilizer in pond culture systems is basically intended to enhance the plankton population, productivity level as well as promotion of fish growth (Chakrabarti and Jana, 1998). Therefore, besides toxicity, castor bean seed powder can be also used as good plant-derived manure in aquaculture due to the presence of $4.3 \%$ total nitrogen, $1.8 \%$ phosphorus and $1.3 \%$ potassium (Ghimire, 2002). The application of manure can boost the available nutrient sources in water and also enhance productivity and plankton populations (Garg et al., 1998). So, plant-based manure can be a good managerial approach in terms of increase of culture efficiency and reducing of cost of fish production.

Usually, Oreochromis mossambicus is considered as low-cost fish and in least demand for aquaculture as the species hampers the culture systems due to its prolific breeding behavior and competition with other species with respect to utilization of food and ecological niches (NFDB, 2015). The uncontrolled overpopulation of tilapia is considered as one of the major challenging issues in the aquaculture sector in India. Indian aquaculture practice is dominated by carp species. Amur common carp has a potential contribution to total aquaculture production. It is considered a good candidate species due to its high growth performance, slender body, hardy nature and better feed utilization efficiency (Basavaraju and Reddy, 2013). Various plant-derived, low cost and locally available materials became popular as piscicides particularly in the moderately intensive inland aquaculture in India and throughout the globe. The herbal piscicide like mohua oil cake is used widely in intensive aquaculture. Currently, the increased market price of good quality mohua oil cake is directed to choose alternative herbal piscicide. Therefore, the present study aimed to investigate the acute toxicity of castor bean powder on tilapia and its residual toxicity on Amur carp so as to act as an alternative, lowcost phyto-piscicide to costly mohua oil cake in carp aquaculture.

\section{MATERIALS AND METHODS}

The present study was conducted for 15 days duration (May, 2019) in the College of Fisheries, Guru Angad Dev Veterinary and Animal Sciences University, Ludhiana, Punjab (30 $54^{\prime} 21.5^{\prime \prime} \mathrm{N}, 75^{\circ} 48^{\prime} 04.7^{\prime \prime}$ E, MSL: $\left.247 \mathrm{~m}\right)$. Comparative evaluation of different dosages of castor bean seed powder was carried out to evaluate the minimum concentration of the CBS for absolute mortality (acute toxicity assessment) on advanced fry of Oreochromis mossambicus followed by the residual toxicity assessment of CBS on advanced fry of Amur carp (Cyprinus carpio haematopterus). After the acute toxicity assessment, Amur carp fry was stocked in the same treatments in which CBS was applied earlier for the residual toxicity assessment. The powder form of castor bean seed was used for toxicity study. Raw castor bean seed (CBS) was procured from Gujarat, India. Castor bean seed was properly sun-dried to remove the moisture and ground to get fine powder form. CBS powder was packaged in air sealant plastic bag for further application. 


\section{Minimum concentration of the CBS for absolute mortality}

The toxicity study was carried out in triplicates for 24 hour with three treatments in an experimental glass aquarium $(56.63 \mathrm{~L}$ each). All the aquaria were cleaned and washed properly as well as disinfected with potassium permanganate $\left(\mathrm{KMnO}_{4}\right)$ solution $\left(2 \mathrm{mgL}^{-1}\right)$. Three different doses $\left(225 \mathrm{mgL}^{-1}, 250 \mathrm{mgL}^{-1}\right.$ and $275 \mathrm{mgL}^{-1}$ ) of powdered castor bean seed (CBS) were applied in three treatments T1 (225 $\left.\mathrm{mgL}^{-1}\right)$, T2 $\left(250 \mathrm{mgL}^{-1}\right)$ and $\mathrm{T} 3\left(275 \mathrm{mgL}^{-1}\right)$, respectively. Healthy pre-acclimatized tilapia fry $(3.81 \pm 0.01 \mathrm{~cm}, 1.76 \pm 0.2 \mathrm{~g})$ was stocked @ 15 numbers in each aquarium.

\section{Gradual decline of CBS effect}

After the acute toxicity assessment on tilapia, the gradual decline of CBS effect (residual toxicity assessment) was carried out on Amur carp for 15 days with three same treatments and one control treatment in triplicates in the same experimental glass aquarium (56.63 L each). Healthy preacclimatized Amur carp fry $(4.32 \pm 0.03 \mathrm{~cm}$, $1.82 \pm 0.4 \mathrm{~g})$ was stocked @ 30 numbers in each aquarium. Amur carp juveniles were procured in well-oxygenated plastic bags from the farm of Central Institute of Freshwater Aquaculture, Kaushalyaganga, Bhubaneswar, Odisha, India. The fishes were conditioned for 2 hours in earthen pond condition. After which, fishes were treated with a mild common salt dip treatment (15-20 $\left.\mathrm{gL}^{-1}\right)$ for 2 min and transferred to a big cemented circular pool. Finally, fishes were transferred to experimental aquariums under aerated condition. The dead fishes were cleaned up and healthy fishes were stocked to maintain the appropriate stocking density.

\section{Mortality, external body signs and behavioral response}

Mortality of tilapia was recorded at every one hour interval for acute toxicity test upto 10 hours of CBS application, whereas, mortality of Amur carp was recorded at every alternate day during the study period. Dead fish was removed from the aquaria by hand net and counted subsequently. The external body signs like colour, mucus, red patches, scale loss, rid gills and hemorrhages were observed in dead fishes. Responses like gasping on the surface of water and changes in swimming patterns were also monitored in both the test fishes.

\section{Collection and analysis of water samples}

Water samples were collected at three days interval. The water samples were collected from each aquarium at a fixed time (09.00-10.00 $\mathrm{AM})$ of a day following all the precautions. Water quality parameters were analyzed following the standard methods (APHA, 1995). Temperature $\left({ }^{\circ} \mathrm{C}\right)$ and $\mathrm{pH}$ of water were measured using a digital $\mathrm{pH}$ meter (ColeParmer $\mathrm{pH}$ Tester). Biological oxygen demand $\left(\mathrm{BOD}_{1}\right)$, dissolved oxygen (DO), total alkalinity (TA), and total hardness (TH) were determined following the standard formula (APHA, 1995). Ammonia-nitrogen $\left(\mathrm{NH}_{3}-\mathrm{N}\right)$, nitrate-nitrogen $\left(\mathrm{NO}_{3}-\mathrm{N}\right)$ and ortho-phosphate $\left(\mathrm{PO}_{4}-\mathrm{P}\right)$ were estimated in UV-vis-Spectrophotometer (HACH DR 6000 model).

\section{Water bacteriological assay}

Microbial densities in water were enumerated at every five days intervals. Serial dilution of water samples from each treatment was prepared and $100 \mu \mathrm{L}$ of proper dilution was spread on a plate. Total aerobic heterotrophic bacteria (AHB), ammonifying bacteria (AB), ammonia oxidizing bacteria (AOB) and phosphate solubilizing bacteria (PSB) were enumerated through the spread plate method (Sanders, 2012). The population of aerobic heterotrophic bacteria was grown in nutrient agar medium supplemented with $1.0 \% \mathrm{w} / \mathrm{v} \mathrm{NaCl}$ (Eaton et al., 1998). The composition of the medium for ammonifying bacteria and ammonia oxidizing bacteria was used as per Alexander (1977). PSB are capable of utilizing tri-calcium phosphate. The production of a clear zone around the colonies of the organisms was an indication of the presence of PSB. The composition of modified Pikovskaya's agar medium was used as per the medium used by Rao (1978). 


\section{Statistical Analysis}

Statistical analysis of the data was carried out using SPSS v. 20. One-way ANOVA and post-hoc Duncan's Multiple Range Test (DMRT) with statistical significance set at $\alpha=0.05$, were used throughout. All data were checked for normality and homogeneity of variance before analysis.

\section{RESULTS}

\section{Mortality of tilapia and Amur carp}

The hourly mortality rate showed that the absolute mortality of tilapia occurred on $6^{\text {th }}$ hours of CBS application in T1, whereas, it was recorded on $7^{\text {th }}$ hours and $9^{\text {th }}$ hours in T3 and T2, respectively (Fig. 1a). A significant difference $(\mathrm{P}<0.05)$ was observed among the treatments. The mortality rate was higher in all the treatments upto first 3 hours of CBS application, whereas, the marginal rate of mortality reduced upto the $10^{\text {th }}$ hour of CBS application in the respective treatment groups (Fig. 1b, 1c, 1d). The cumulative mortality rate of tilapia was showed a significant difference $(\mathrm{P}<0.05)$ among the treatments and the highest mortality rate was observed in T3 $(72 \%)$ and lowest in T1 (42\%) (Fig. 1b, 1c, 1d). The cumulative mortality rate increased over time and $50 \%$ of tilapia mortality was observed within 3-4 hours of CBS application in T2 and $\mathrm{T} 3$, whereas, it was 5-6 hours in T1. The residual effect of CBS toxicity on Amur carp showed that $\geq 50 \%$ mortality was observedon the $3^{\text {rd }}$ day of CBS application (mortality T1-50.00\%, T2$53.00 \%$ and $\mathrm{T} 3-46.67 \%$ ). The mean difference among the treatment was not significant $(\mathrm{P}>0.05)$. The mortality rate reduced to less than $10 \%$ in $\mathrm{T} 1$ and $\mathrm{T} 2$ on the $12^{\text {th }}$ day of the study period (Fig. 1e). The observations on the external behavior of both tilapia and Amur carp on the application of CBS indicated that tilapia became inactive gradually, lost their balance and gasping on the surface of the water (Table 1). Also, Amur carp showed erratic movement and released more mucus in water in all the CBS treatments. Amur carp did not show any abnormal behavior and responses in the control treatment.

\section{Water quality parameters and microbial populations}

All the water quality parameters are presented in Table 2. The surface water temperature remained within $25-27^{\circ} \mathrm{C}$ during the period of the experiment. Water temperature increased up to the $1^{\text {st }}$ half, after which it decreased during the rest of the study period. The $\mathrm{pH}$ of water increased gradually upto the first 5 days after which it declined in all the treatments except in the control group and remained in alkaline conditions (7.13-8.2) with a significant $(\mathrm{P}<0.05)$ treatment difference (Fig. 2a). $\mathrm{pH}$ was highest in control and lowest in T2. A similar trend was observed for alkalinity,

Table 1. External behavior and body sign of tilapia and Amur carp

\begin{tabular}{lllllll}
\hline & & Tilapia & \multicolumn{3}{c}{ Amur carp } \\
& T1 & T2 & T3 & T1 & T2 & T3 \\
\cline { 2 - 7 } Loss of balance & Low & Medium & High & Medium & Medium & High \\
Erratic movement & Medium & High & High & Low & Medium & High \\
Gasping at water surface & High & High & High & Low & High & High \\
Loss of scales and fins & Less & More & More & Less & More & More \\
Gill colour & Light & Reddish & Dark & Faint & Dark & Dark \\
& brown & brown & brown & reddish & brown & brown \\
Mucus secretion & High & High & High & Low & Medium & High \\
Red patches & Less & Less & More & Less & Less & More \\
Scale loss & More & More & More & Less & Less & More \\
Hemorrhages & Less & More & More & Less & Less & More \\
\hline
\end{tabular}


Toxicity assessment of castor bean (Ricinus communis) seed in aquaculture

Table 2. Water quality variables in different treatments $($ Mean \pm S.E. $)$

\begin{tabular}{|c|c|c|c|c|}
\hline \multirow[b]{2}{*}{ Variables } & \multicolumn{4}{|c|}{ Treatment (Mean \pm S.E.) } \\
\hline & $\mathbf{T 1}$ & $\mathbf{T 2}$ & T3 & $\mathbf{C}$ \\
\hline Temp. $\left({ }^{\circ} \mathrm{C}\right)$ & 27.30 & 27.32 & 27.35 & 27.31 \\
\hline $\mathrm{pH}$ & $7.23-8.20$ & $7.13-8.10$ & $7.16-8.20$ & $7.86-8.13$ \\
\hline $\mathrm{DO}\left(\mathrm{mgL}^{-1}\right)$ & $5.04 \pm 0.65 \mathrm{ab}$ & $4.59 \pm 0.63^{\mathrm{a}}$ & $4.42 \pm 0.63$ a & $7.39 \pm 0.08^{c}$ \\
\hline $\mathrm{BOD}_{1}\left(\mathrm{mgL}^{-1}\right)$ & $2.48 \pm 0.38^{c}$ & $2.08 \pm 0.28^{\mathrm{bc}}$ & $1.91 \pm 0.23^{b}$ & $1.64 \pm 0.05^{\mathrm{a}}$ \\
\hline $\mathrm{TA}\left(\mathrm{mgL}^{-1}\right)$ & $236.38 \pm 24.80^{\mathrm{a}}$ & $239.83 \pm 24.56^{\mathrm{a}}$ & $231.00 \pm 27.07^{\mathrm{a}}$ & $334.78 \pm 2.02^{b}$ \\
\hline $\mathrm{TH}\left(\mathrm{mgL}^{-1}\right)$ & $222.67 \pm 6.25^{\mathrm{a}}$ & $211.22 \pm 8.82^{\mathrm{a}}$ & $210.72 \pm 9.20^{\mathrm{a}}$ & $237.61 \pm 1.54^{b}$ \\
\hline $\mathrm{NH}_{3}-\mathrm{N}\left(\mathrm{mgL}^{-1}\right)$ & $0.058 \pm 0.01^{\mathrm{b}}$ & $0.069 \pm 0.015^{\mathrm{c}}$ & $0.077 \pm 0.018^{\mathrm{d}}$ & $0.024 \pm 0.000^{\mathrm{a}}$ \\
\hline $\mathrm{NO}_{3}-\mathrm{N}\left(\mathrm{mgL}^{-1}\right)$ & $0.386 \pm 0.062$ & $0.421 \pm 0.07$ & $0.403 \pm 0.067$ & $0.116 \pm 0.007$ \\
\hline $\mathrm{O}-\mathrm{PO}_{4}\left(\mathrm{mgL}^{-1}\right)$ & $0.055 \pm 0.006^{b}$ & $0.064 \pm 0.007^{\mathrm{b}}$ & $0.064 \pm 0.008^{b}$ & $0.031 \pm 0.001^{a}$ \\
\hline $\mathrm{N}: \mathrm{P}$ ratio & $7.76 \pm 0.45^{\mathrm{c}}$ & $7.42 \pm 0.47^{\mathrm{b}}$ & $7.35 \pm 0.48^{b}$ & $4.66 \pm 0.45^{\text {a }}$ \\
\hline
\end{tabular}

Mean with different superscripts within row differs significantly $(\mathrm{P}<0.05)$

Abbreviation: Temp.- Temperature, DO- Dissolved oxygen, BOD- Biological oxygen demand, TA- Total alkalinity, TH- Total hardness, $\mathrm{NH}_{3}-\mathrm{N}$ - Ammonia -nitrogen, $\mathrm{NO}_{3}-\mathrm{N}$ - Nitrate-nitrogen, O- $\mathrm{PO}_{4}$ - Ortho-phosphate, N:P- Nitrogen and phosphorus ratio

hardness and $\mathrm{BOD}_{1}$ level in the water (Fig. 2b, $2 \mathrm{c}, 2 \mathrm{~d})$. The dissolved oxygen level decreased upto 5 days after which it increased in all the treatments except in the control group in which the trend remained almost stationary (Fig. 2e).

Total inorganic nitrogen concentration increased but remained more or less stationary with a significant difference $(\mathrm{P}<0.05)$ among the treatments. The ammonia-nitrogen concentration increased during the first 5 days and then it continued to decline (Fig. 3a). The nitrate-nitrogen concentrations increased over time in all the treatments except in control with significant difference $(\mathrm{P}<0.05)$ among the treatments (Fig. 3b). The ortho-phosphate concentration increased in all the treatments except in the control and showed a significant difference $(\mathrm{P}<0.5)$ among the treatments (Fig.3c). A similar trend was noticed with a significant difference $(\mathrm{P}<0.05)$ for the $\mathrm{N}: \mathrm{P}$ ratio in all the treatment groups (Fig. 3d).

Populations of AHB, AB, AOB and PSB gradually increased in all the treatments except control after the $5^{\text {th }}$ day of the study period with a significant difference $(\mathrm{P}<0.05)$ among the treatments. The mean population of $\mathrm{AHB}, \mathrm{AB}$, $\mathrm{AOB}$ and PSB were highest in $\mathrm{T} 3$ followed by T2, T1 and C (Table 3).

Table 3. Microbial populations in water in different treatments $(M e a n \pm S . E$.

\begin{tabular}{lcccc}
\hline Variables & \multicolumn{4}{c}{ CFU $\left(\log\right.$ No. $\left.\mathbf{~ m L}^{-1}\right)$} \\
\cline { 2 - 5 } & T1 & T2 & T3 & C \\
\hline AHB & $3.04 \pm 0.01^{\mathrm{b}}$ & $3.14 \pm 0.01^{\mathrm{c}}$ & $3.23 \pm 0.01^{\mathrm{d}}$ & $2.71 \pm 0.01^{\mathrm{a}}$ \\
AB & $2.99 \pm 0.02^{\mathrm{b}}$ & $3.13 \pm 0.01^{\mathrm{c}}$ & $3.26 \pm 0.01^{\mathrm{d}}$ & $2.74 \pm 0.02^{\mathrm{a}}$ \\
AOB & $2.88 \pm 0.02^{\mathrm{b}}$ & $3.12 \pm 0.01^{\mathrm{c}}$ & $3.26 \pm 0.01^{\mathrm{d}}$ & $2.77 \pm 0.02^{\mathrm{a}}$ \\
PSB & $2.94 \pm 0.02^{\mathrm{b}}$ & $3.16 \pm 0.01^{\mathrm{c}}$ & $3.28 \pm 0.02^{\mathrm{d}}$ & $2.73 \pm 0.01^{\mathrm{a}}$ \\
\hline
\end{tabular}

Mean with different superscripts within row differs significantly $(\mathrm{P}<0.05)$

Abbreviation: AHB- Aerobic heterotrophic bacteria, AB- Ammonifying bacteria, AOB- Ammonia oxidizing bacteria, PSB- Phosphate solubilizing bacteria 

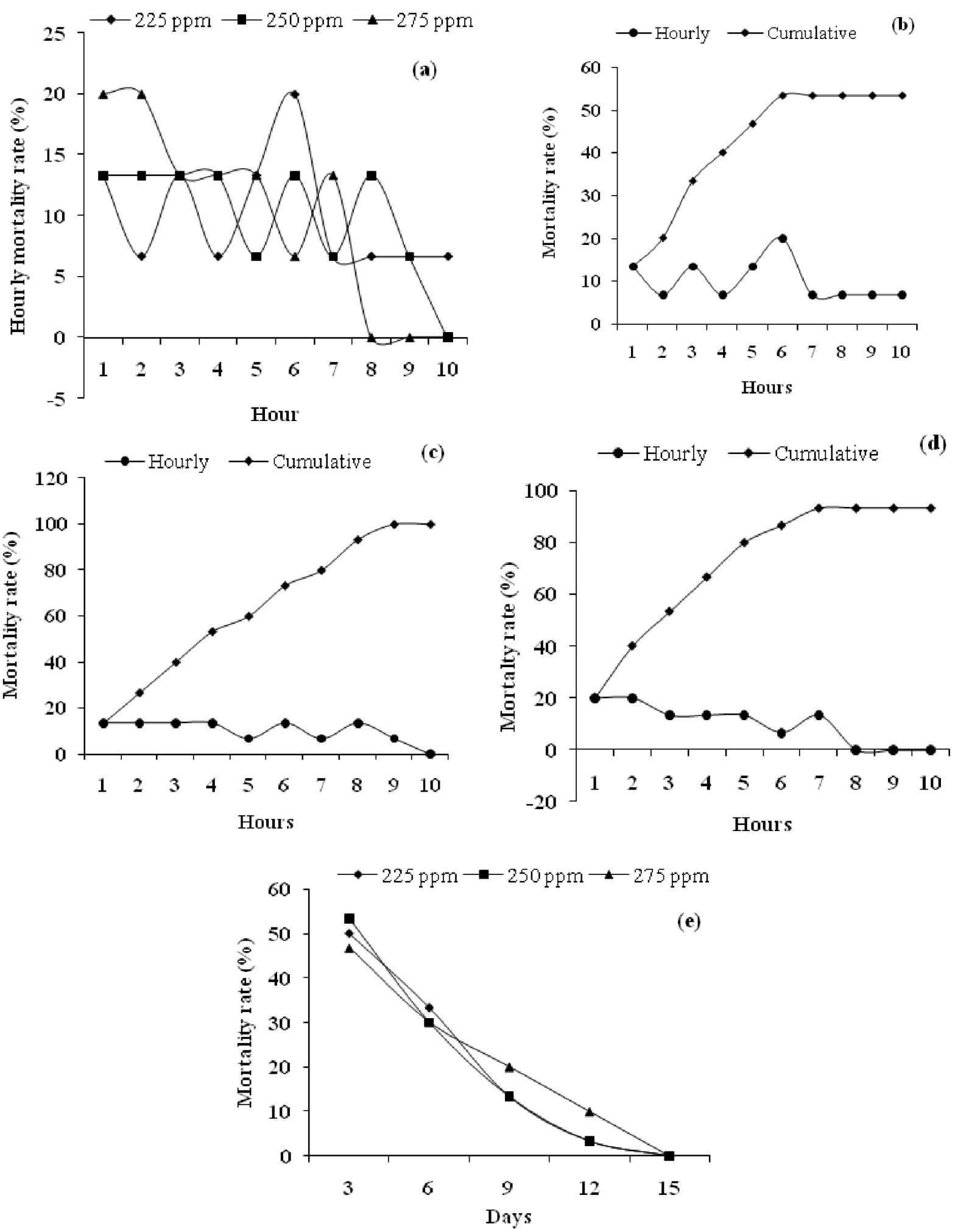

Fig. 1. Temporal changes of hourly mortality rate of tilapia in different treatments (a), hourly mortality rate vs. cumulative mortality rate in $\mathrm{T} 1$ (b), $\mathrm{T} 2$ (c), $\mathrm{T} 3$ (d) and residual effect of CBS on mortality rate of Amur carp (e) 
Toxicity assessment of castor bean (Ricinus communis) seed in aquaculture

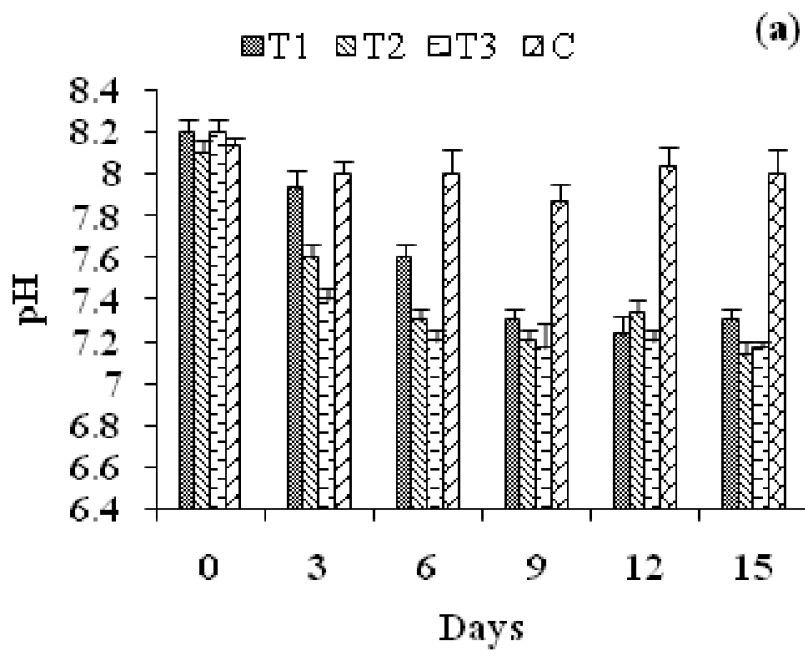

(a)

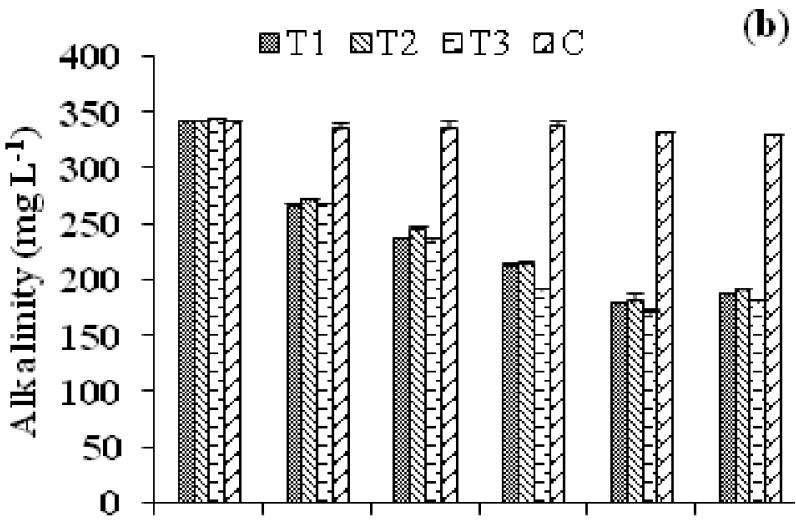

(b)

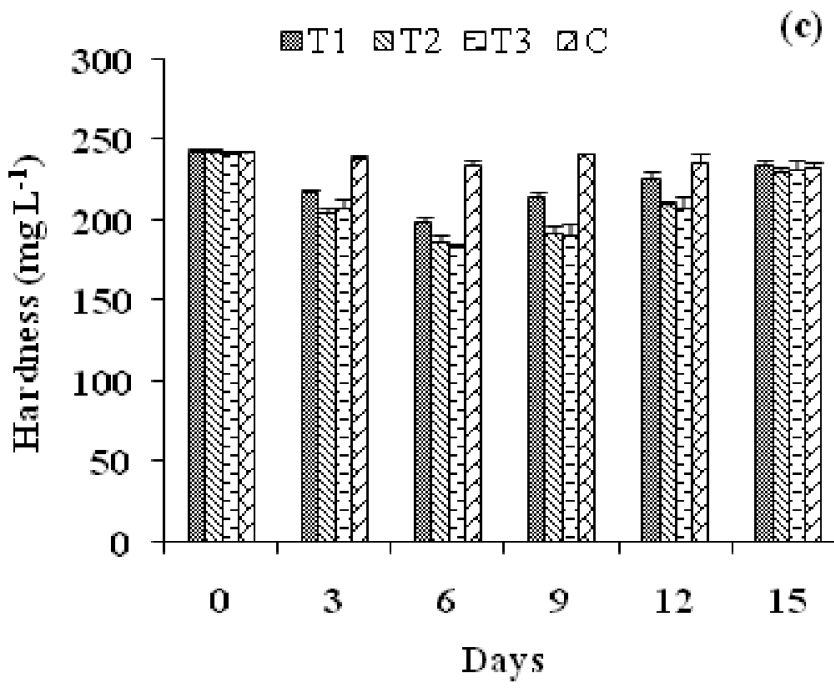

T1 $₫ \mathrm{~T} 2 \quad \mathrm{TT} 3 \quad \mathrm{CC} \quad$ (d)

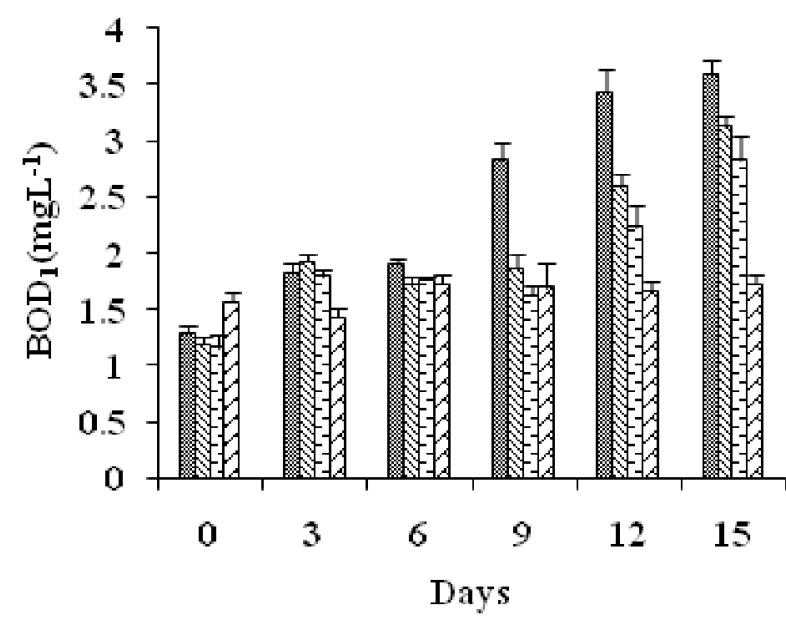

田1 $\$ \mathrm{~T} 2$ घT3 $\mathrm{DC}$

(e)

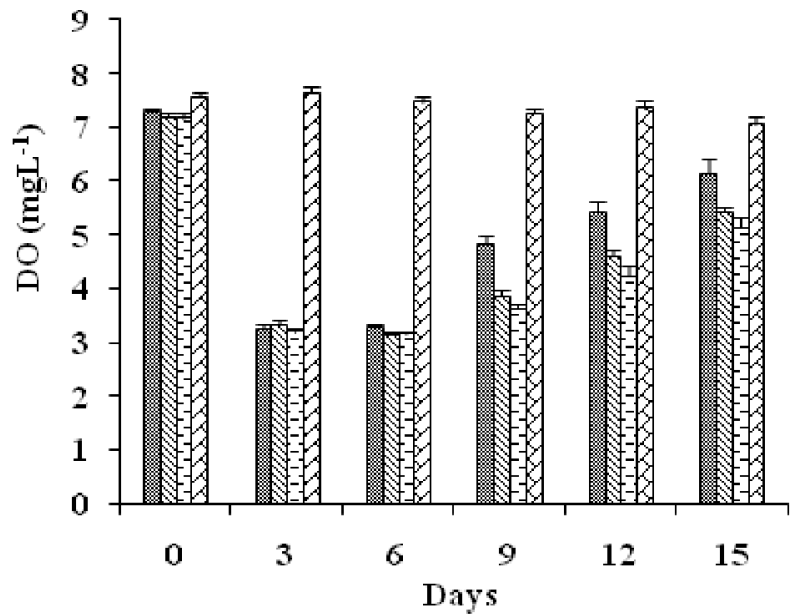

Fig. 2. Temporal changes of pH (a), alkalinity (b), hardness (c), BOD $(d)$ and DO (e) in different treatments 

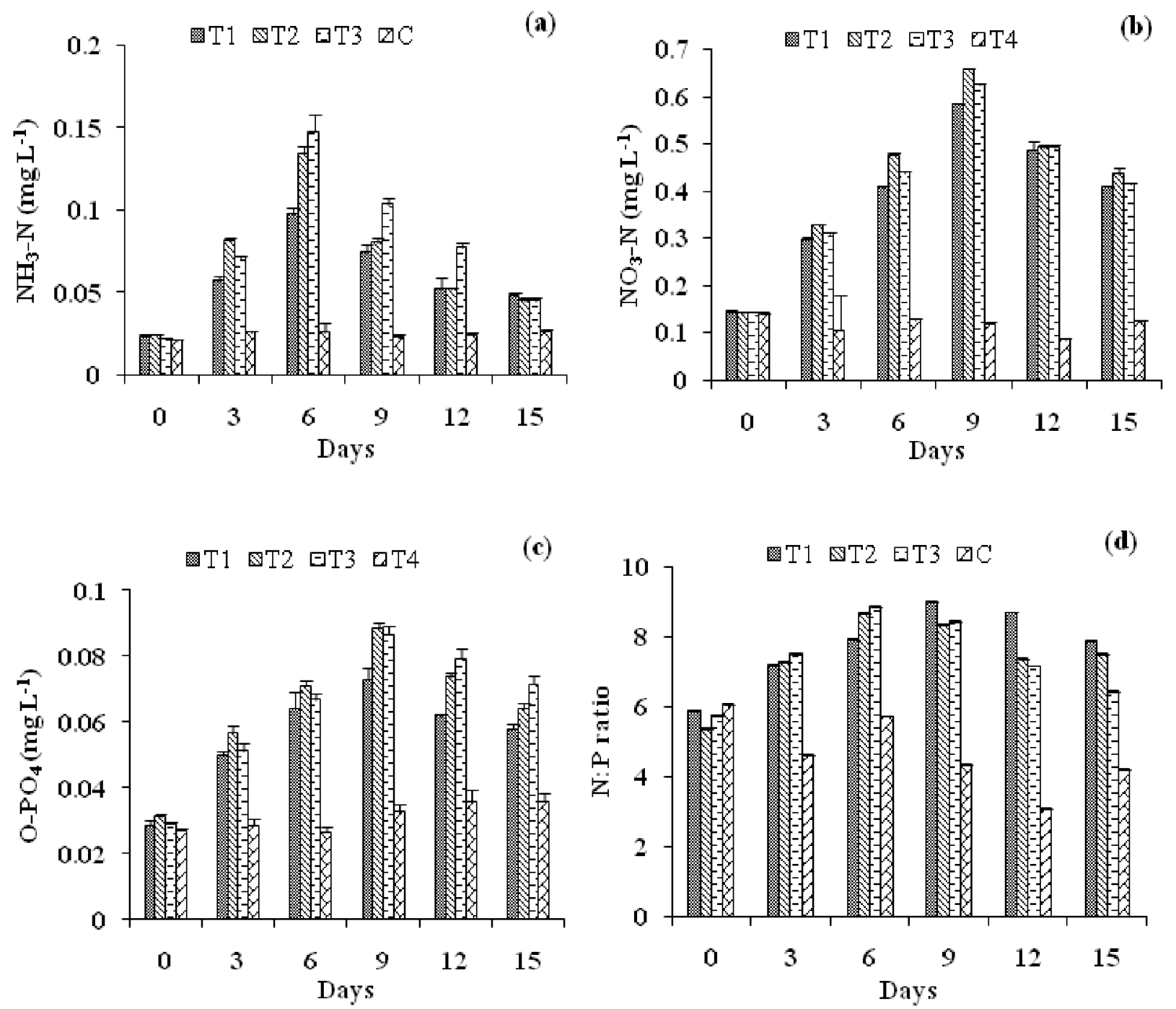

Fig. 3. Temporal changes of $\mathrm{NH}_{3}-\mathrm{N}(\mathrm{a}), \mathrm{NO}_{3}-\mathrm{N}(\mathrm{b})$, Ortho-phosphate(c), and $\mathrm{N}: \mathrm{P}$ ratio (d) in different treatments

\section{DISCUSSION}

The hourly mortality rate of tilapia showed that the absolute mortality rate was faster in $\mathrm{T} 1\left(225 \mathrm{mgL}^{-1}\right)$ compared to the rest of the treatments. The cumulative mortality rate of tilapia was highest in $\mathrm{T} 3\left(275 \mathrm{mgL}^{-1}\right)$ followed by $\mathrm{T} 2\left(250 \mathrm{mgL}^{-1}\right)$ and $\mathrm{T} 1\left(225 \mathrm{mgL}^{-1}\right)$. A more than $50 \%$ mortality of tilapia observed on 3-4 hours of CBS application, this implied that the positive toxic effect of CBS which can be used as a potent piscicidal agent besides other piscicide like mohua oil cake, tea seed cake etc. (Mondal and Das, 2019). Therefore, the lethal dose of CBS may be considered within 225-250 $\mathrm{mgL}^{-1}$ to act as a potent piscicidal agent in aquaculture. The higher cumulative mortality rate in $275 \mathrm{mgL}^{-1}$ compared to other treatments suggested that the absolute mortality $(100 \%)$ of tilapia was achieved with the increase in time ( $9^{\text {th }}$ to $10^{\text {th }}$ hours). This might be due to the presence of high level of toxic antimetabolites glycoprotein and ricin with increasing level of CBS dose as the polynomial relationship 
(Fig. 4) was established between cumulative mortality rate of tilapia and the linear relationship with CBS dose (Fig. 5) as well as also with the duration of exposure. Aslania et al. (2007) reported that castor bean intoxication has a relatively long latency period. The $50 \%$ mortality of tilapia was achieved within 3-4 hours of CBS powder application within the dose $235 \mathrm{mgL}^{-1}$ to $240 \mathrm{mgL}^{-1}$ which can be considered as $\mathrm{LD}_{50}$ (Lethal Dose, $50 \%$ ) of CBS powder.

Audi et al. (2005) reported that the presence of A-chain of glycoprotein lectin in ricin have the negative effect on fish cell as those inhibit the protein synthesis which causes the blocking of ribosomal activity leads cell death. As a result, the hourly mortality rate was faster and the cumulative mortality rate was slower due to the delayed response of CBS toxicity. Whereas, the mortality rate of Amur carp reduced from the $3^{\text {rd }}$ day of the study, this may be related to the gradual reduction of the toxic effect of CBS. The findings are in agreement with earlier reports in Labeo bata (Mondal and Das, 2019) and higher animal like rat (Cook et al., 2006). The absolute mortality of tilapia, reduced mortality of Amur carp and reclamation of water quality were more identical on the $6^{\text {th }}$ day of the study as the mortality rate of Amur carp reduced $\leq 10 \%$ which suggested that the toxic effect of CBS continued upto 10 days in aquaculture practices (Fig. 6). The duration of the residual toxicity, as well as reclamation of water quality in later, was in conformity with the recommendation of the Aquaculture Authority (1999) which suggested the fish can be restocked in aquaculture system after 10 days of piscicide application.

In the present study, the decrease of $\mathrm{pH}$ in CBS treatments might be due to the gradual decomposition of CBS which led to mineralization of organic matter (Krachler et al., 2009; Mondal and Das, 2019). The decomposition of organic matter reduced the dissolved oxygen level in water. The reduction of alkalinity level in water was parallel to $\mathrm{pH}$ level in water. Also, the BOD level increased due to the presence of high microbial load of the heterotrophic bacterial population as negative polynomial relationships were established between dissolved oxygen, $\mathrm{BOD}_{1}$ and heterotrophic bacteria (Fig. 7). The increased level of total inorganic nitrogen and ortho-phosphate concentrations might be because of the high level of nitrogen and phosphorus in CBS (Ghimire, 2002; Mondal and Das, 2019).

The increased N:P ratio in all the CBS treatments increased gradually and remained identical between 7.35-7.75 which was within the optimal level (4:1 to 8:1) in the aquaculture production system (Ghosh and Chattopadhyay, 2005). This was established with the polynomial relation between $\mathrm{N}: \mathrm{P}$ ratio and mineralizing bacterial population (Table 4). Mandal and Das (2019) reported that CBS treatment caused phosphorus limitation to maintain congenial $\mathrm{N}: \mathrm{P}$ ratio in the aquaculture system.

Table 4. Polynomial relationship between N:P ratio and mineralizing bacterial populations

\begin{tabular}{llll}
\hline & \multicolumn{1}{c}{ T1 } & \multicolumn{1}{c}{ T2 } & \multicolumn{1}{c}{ T3 } \\
\hline N:Pvv. AHB & $y=-4.883 x^{2}+11.97 x+2.147 ;$ & $y=-0.947 x^{2}+3.872 x+4.348 ;$ & - \\
& $R^{2}=0.885$ & $R^{2}=0.552$ & \\
N:Pvs. AB & $y=-8.982 x^{2}+19.81 x-2.567 ;$ & $y=-6.599 x^{2}+18.26 x-1.987 ;$ & $y=-2.535 x^{2}+8.838 x+1.694 ;$ \\
& $R^{2}=0.947$ & $R^{2}=0.873$ & $R^{2}=0.972$ \\
N:Pvs. AOB & $y=6.013 x^{2}-7.899 x+9.044 ;$ & $y=-5.619 x^{2}+15.18 x-0.261 ;$ & $y=-2.322 x^{2}+7.880 x+2.479 ;$ \\
& $R^{2}=0.467$ & $R^{2}=0.984$ & $R^{2}=0.992$ \\
N:Pvs.PSB & $y=7.493 x^{2}-11.74 x+10.97 ;$ & $y=-3.952 x^{2}+11.56 x+0.713 ;$ & $y=-2.061 x^{2}+7.312 x+2.484 ;$ \\
& $R^{2}=0.401$ & $R^{2}=0.976$ & $R^{2}=0.973$ \\
\hline
\end{tabular}




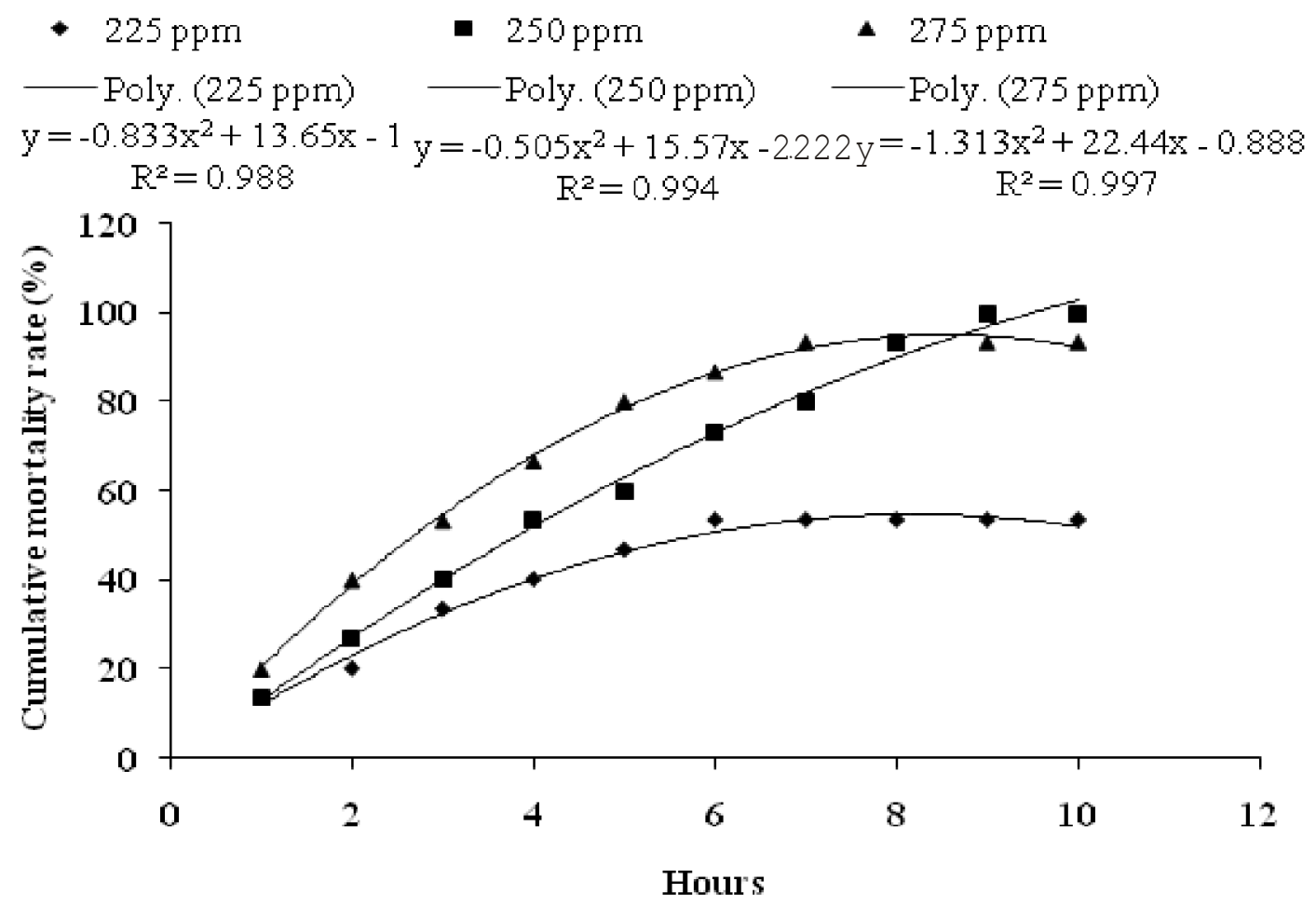

Fig. 4. Polynomial relationship between cumulative mortality rate of tilapia with hours of observation

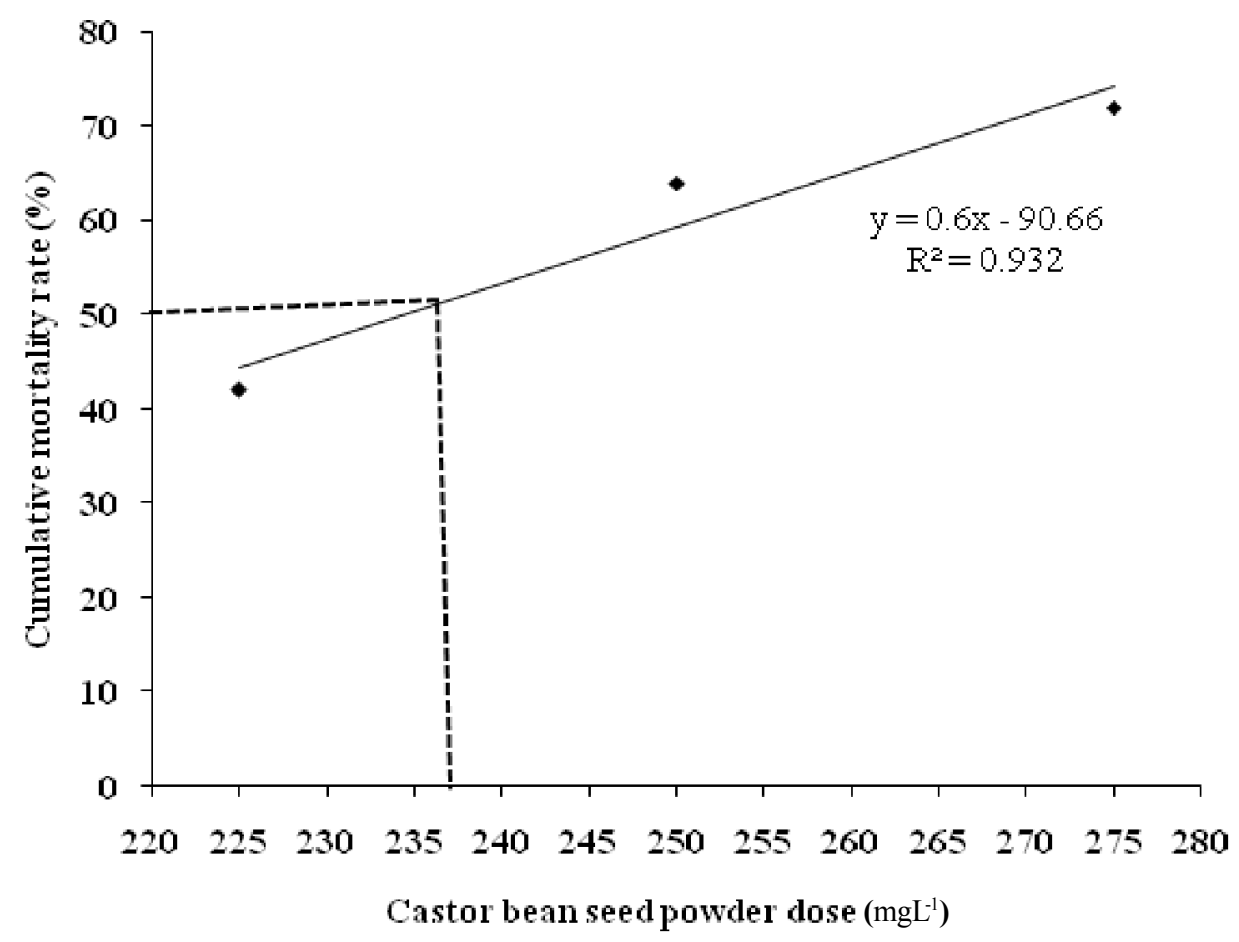

Fig. 5. Linear relationship between cumulative mortality rate of tilapia with CBS powder dose 


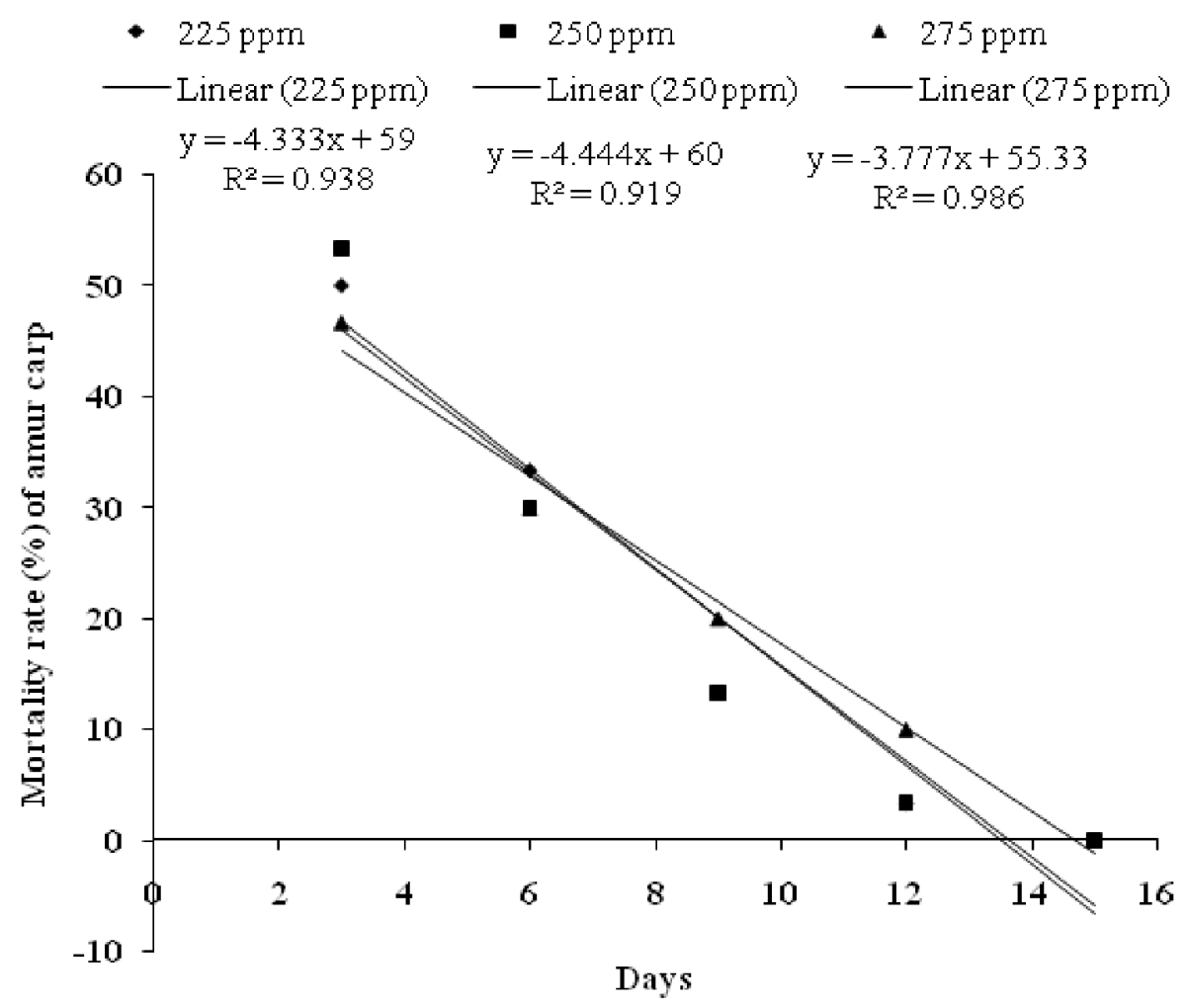

Fig. 6. Linear relationship between mortality rate of Amur carp and duration of experiment

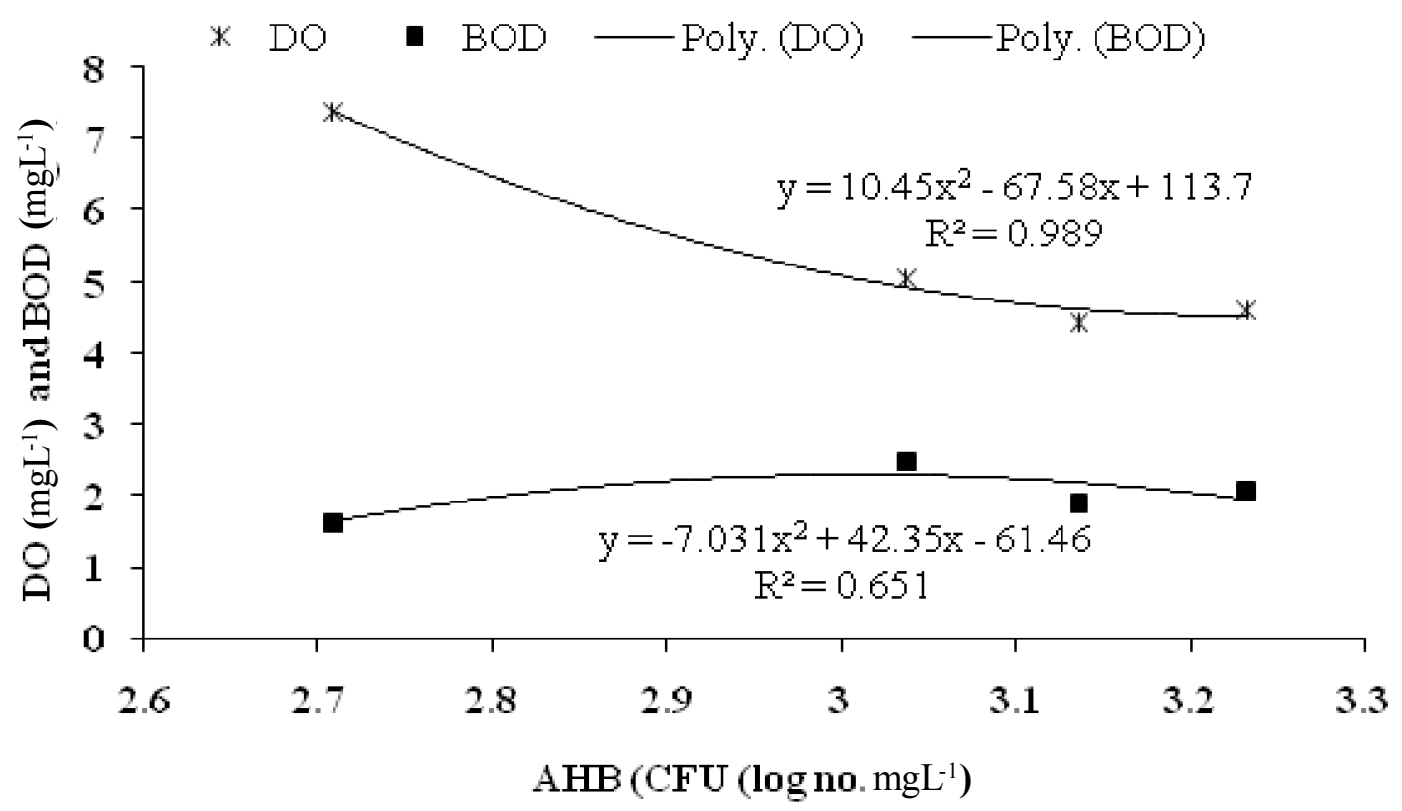

Fig. 7. Polynomial relationship between dissolved oxygen, biological oxygen demand with aerobic heterotrophic bacterial population in water 
The lethal dose $\left(\mathrm{LD}_{50}\right)$ of castor bean seed powder might be considered within 235 $\mathrm{mgL}^{-1}$ to $240 \mathrm{mgL}^{-1}$. The optimum level of castor bean seed powder application might be within $225 \mathrm{mgL}^{-1}$ to $250 \mathrm{mgL}^{-1}$ as higher dose $275 \mathrm{mgL}^{-1}$ showed no significant difference with $225 \mathrm{mgL}^{-1}$ and $250 \mathrm{mgL}^{-1}$ in terms of absolute mortality of tilapia. The toxicity level of castor bean seed powder reduced over time as evident from the reduced mortality rate of Amur carp and the N:P ratio in water enhanced through the activity of the mineralizing bacterial population. Though the mortality rate of tilapia and residual effect on Amur carp were higher in the higher dose of CBS $\left(275 \mathrm{mgL}^{-1}\right)$, nutrient mineralization and $\mathrm{N}: \mathrm{P}$ ratio did not exert any

\section{REFERENCES}

Alexander M, 1977. Introduction to soil microbiology. JohnWiley Eastern Ltd, New Delhi, pp 467

Anjani K, 2014. A re-evaluation of castor (Ricinus communis L.) as a crop plant. CAB Reviews, 9(038):1-21, doi: 10.1079/PAVSNNR2 0149038

APHA, 1995. Standard Methods for the Examination of Water and Waste water ( $16^{\text {th }}$ edn.). American Public Health Association, American Water Works Association and Water Pollution Control Federation, Washington D.C, pp 129

Aquaculture Authority, 1999. Adopting improved technology for increasing production and productivity in traditional and improved traditional systems of shrimp farming. Ministry of Agriculture, New Dehli, India, pp 14

Aslania MR, Maleki M, Mohri M, Sharifi K, Najjar-Nezhad V et al., 2007. Castor bean (Ricinus communis) toxicosis in a sheep flock. Toxicon, 49(3): 400-406, doi: 10.1016/ j.toxicon.2006.10.010

Audi J, Belson M, Patel M, Schier J and Osterloh J, 2005. Ricin poisoning- A comprehensive review. J Am Med Asso, 294(18): 2342-2351, doi: 10.1001/jama.294.18.2342

Basavaraju Y and Reddy AN, 2013. Growth performance of Amur strain of common carp in southern Karnataka. Mysore J Agri Sci, 47(1): 119-123

Chakrabarti R and Jana BB, 1998. Effects on growth and water quality of feeding exogenous plankton compared to use of manure in the significant difference with lower doses (225 $\mathrm{mgL}^{-1}$ and $250 \mathrm{mgL}^{-1}$ ). Therefore, the application rate of CBS powder as a potential piscicidal agent may be considered within $225 \mathrm{mgL}^{-1}$ to $250 \mathrm{mgL}^{-1}$ in the aquaculture production system for maintaining the suitable ecological status.

Conflict of interest: Authors have no conflict of interest in this study.

\section{ACKNOWLEDGEMENT}

The work was supported by the institutional grant. Authors are thankful to the Dean, College of Fisheries, GADVASU for providing all the requirements for conducting the research work.

culture of Mrigal, Cirrhinus mrigala, and Rohu, Labeo rohita fry is tanks. J Appl Aquac, 8(2): 87-95, doi: 10.1300/J028v08n02_09

Chatterjee S and Ganguli S, 1993. Effect of mahua oil cake on the blood of the fish Clarias batrachus. Environ Ecol, 11(4): 888-891

Cook DL, David J and Griffiths GD, 2006. Retrospective identification of ricin in animal tissues following administration by pulmonary and oral routes.Toxicol, 223(1): 61-70, doi: 10.1016/j.tox.2006.03.010

Das SK, Mondal B, Biswas B and Mandal A, 2018. Herbal piscicides in inland aquaculture- A review. J Ecol Natr Resources, 2(3): 000133, doi: $10.23880 /$ jenr-16000133

Das SK, Sarkhel C, Mandal A and Dinda R, 2017. Piscicides in tropical freshwater aquacultureAn overview. Indian J Anim Health, 56(1): 11-30

Eaton AD, Clesceri LS, Greenberg AE and Franson MAH, 1998. Standard Methods for the Examination of Water and Wastewater. 20 ${ }^{\text {th }}$ edn., American Public Health Association, Washington, DC

European Food Safety Authority (EFSA), 2008. Ricin (from Ricinus communis) as undesirable substances in animal feed. Scientific Opinion of the Panel on Contaminants in the Food Chain. EFSA J, 6(9): 726, doi: 10.2903/ j.efsa.2008.726

FAO, 2020. The State of World Fisheries and Aquaculture- Sustainability in action. Rome, 
pp 244, doi: 10.4060/ca9229en

Garg SK, Bhatnagar A and Narula N, 1998. Application of Azotobacter enhances pond productivity and fish biomass in still water ponds. Aquac Int, 6: 219-231, doi: 10.1023/A:1009254727404

Ghimire A, 2002. A Review on Organic Farming for Sustainable Agriculture. Chitwan, Nepal: Department of Agriculture Extension and Rural Sociology, Inst. of Agricult. and Animal Sci. Rampur. Available in http://www.fores tryne pal.org/Blogs/ ghimireananta'sblog/

Ghosh M and Chattopadhyay NR, 2005. Effects of carbon/nitrogen/phosphorus ratio on mineralizing bacterial population in aquaculture systems. J Appl Aquac, 17(2): 8598, doi: 10.1300/J028v17n02_07

Johnson RC, Lemire SW, Woolfitt AR, Ospina M, Preston KP et al., 2005. Quantification of ricinine in rat and human urine: A biomarker for ricin exposure. J Anal Toxicol, 29(3):149155, doi: 10.1093/jat/29.3.149

Katewa SS, Jain A, Chaudhary BL and Galav P, 2005. Some unreported medicinal uses of plants from the tribal area of Southern Rajasthan. Bull Bot Surv India, 47(1-4): 121-130, doi: 10.20324/ nelumbo/v47/2005/74121

Krachler RF, Krachler R, Stojanovic A, Wielander B and Herzig A, 2009. Effects of $\mathrm{pH}$ on aquatic biodegradation processes. Biogeosci Discuss, 6: 491-514, doi: 10.5194/bgd-6-491-2009

Lin TTS and Li SSL, 1980. Purification and physiochemical properties of ricins and agglutinins from Ricinus communis. Eur $\mathrm{J}$
Biochem, 105(3): 453-459, doi: 10.1111/ j.1432-1033.1980.tb04520.x

Mahapatra BC and Thosar VR, 1999. Toxicity of plants and their derivatives on fishes. In: Bull Environ Contamin Toxicol, pp 360-371

Mondal B and Das SK, 2019. Comparative evaluation of mahua (Bassia latifolia) oil cake and castor bean (Ricinus communis) seed as fish toxicants for tilapia (Oreochromis mossambicus) and panchax (Aplocheilus panchax) with residual toxicity assessment on Labeo bata. Aquac Res, 50(9): 2341-2349, doi: 10.1111/are.14115

National fisheries Development Board (NFDB), 2015. Guidelines for Responsible Farming of Tilapia in India, Department of Animal Husbandry, Dairying and Fisheries, Government of India, New Delhi, pp 1-16

Rao VA, 1978. Bioremediation technology to maintain healthy ecology in aquaculture ponds. Fishing Chimes, 22(6): 39-42

Sanders ER, 2012. Aseptic laboratory techniques: plating methods. J Vis Exp, 63: e2754, doi: $10.3791 / 2754$

Tiwari S and Singh A, 2003. Control of common freshwater predatory fish, Channa punctatus, through Nerium indicum leaf extracts. Chemosphere, 53(8): 865-875, doi: 10.1016/ S0045-6535(03)00595-2

Woo BH, Lee JT and Lee KC, 1998. Purification of sepharose-unbinding ricin from castor beans (Ricinus communis) by hydroxyapatite chromatoography. Protein Exp Purif, 13(2): 150-154, doi: $10.1006 /$ prep. 1998.0880

Received - 11.04.2021, Accepted - 15.05.2021, Published - 01.06.2021

Section Editor: Prof. T. J. Abraham, Associate Editor 